J. Dairy Sci. 97:1725-1729

http://dx.doi.org/10.3168/jds.2013-7129

(C) American Dairy Science Association ${ }^{\circledR}, 2014$.

\title{
Short communication: Comparison of 3 solid digesta passage markers in dairy cows
}

\author{
C. Lee and A. N. Hristov ${ }^{1}$ \\ Department of Animal Science, Pennsylvania State University, University Park 16802
}

\begin{abstract}
This study investigated the usefulness of acid-detergent fiber-bound ${ }^{15} \mathrm{~N}$ [acid detergent insoluble (ADI)$\left.{ }^{15} \mathrm{~N}\right]$ as a solid digesta passage marker in dairy cows compared with chromium $(\mathrm{Cr})$ and ytterbium ( $\mathrm{Yb}$ ) (as labeled fiber or forage, respectively). Intrinsically (ADI${ }^{15} \mathrm{~N}$ ) or extrinsically $(\mathrm{Cr}, \mathrm{Yb})$ labeled alfalfa hay was pulse-dosed intraruminally to 7 lactating dairy cows. Following marker administration, spot fecal samples were collected for up to $72 \mathrm{~h}$ for marker analyses. Urine and milk samples were also collected and analyzed for $\mathrm{Yb}$ and $\mathrm{Cr}$. Fecal marker excretion data were processed using 2-compartment mathematical age-dependent/ age-independent $\left(\mathrm{G}_{\mathrm{n}} \rightarrow \mathrm{G}_{1}\right)$ models. The rate of passage of the marker in the first, age-dependent compartment tended to be slower for $\mathrm{Yb}$ compared with $\mathrm{Cr}$ and ADI${ }^{15} \mathrm{~N}$, which resulted in a trend for longer mean retention time (MRT) in this compartment when $\mathrm{Yb}$ was used as a marker $(19.0 \mathrm{~h})$ compared with $\mathrm{Cr}$ and ADI- ${ }^{15} \mathrm{~N}(14.5$ and $13.9 \mathrm{~h}$, respectively). The rate constant of marker disappearance for the second or age-independent compartment tended to be greater for $\mathrm{Yb}$ compared with $\mathrm{Cr}$ and $\mathrm{ADI}-{ }^{15} \mathrm{~N}$, which led to a shorter MRT of $\mathrm{Yb}$ in this compartment (15.6) versus ADI- ${ }^{15} \mathrm{~N}$ (32.1) and $\mathrm{Cr}$ $(24.8 \mathrm{~h})$. The cumulative MRT was greater for ADI- ${ }^{15} \mathrm{~N}$ versus $\mathrm{Cr}$ and $\mathrm{Yb}(46.0,39.3$, and $34.4 \mathrm{~h}$, respectively). Total MRT of marker tended to be greater for ADI- ${ }^{15} \mathrm{~N}$ than for $\mathrm{Yb}$ (46.6 vs. $36.6 \mathrm{~h}$, respectively). Urine and milk analyses data suggested no measurable losses of $\mathrm{Yb}$ along the digestive tract, but about $0.79 \%$ of $\mathrm{Cr}$ dosed intraruminally was secreted or excreted in milk and urine in the 48-h period following marker administration. Collectively, this study confirmed previous observations that $\mathrm{ADI}-{ }^{15} \mathrm{~N}$ can be used reliably as a solid digesta passage marker for ruminants, producing pre-duodenal and total-tract retention times similar to that of Cr-labeled fiber. Retention time in the age-independent compartment was underestimated when $\mathrm{Yb}$
\end{abstract}

Received June 12, 2013.

Accepted December 5, 2013.

${ }^{1}$ Corresponding author: anh13@psu.edu was used as a marker, emphasizing the need to process forages to isolate fiber before labeling with $\mathrm{Yb}$.

Key words: passage rate marker, ytterbium, chromium, nitrogen-15, dairy cow

\section{Short Communication}

Passage rate is a critical component of the digestion process in all farm species but is of particular importance in ruminants because of the extensive fermentation process occurring in the reticulo-rumen. Without reliable estimates of nutrient passage rates and retention time in the reticulo-rumen and the total digestive tract, accurate prediction of diet digestibility and its digestible energy and metabolizable protein value is not possible (NRC, 2001). Because of its importance, numerous experiments have been conducted and techniques and prediction models developed to study digesta passage rate (Shellenberger and Kesler, 1961; Ellis et al., 1994; Seo et al., 2006, 2009; Krizsan et al., 2010).

Several dietary (and animal) factors can influence passage rate in dairy cattle, but the most important one is DMI (Shellenberger and Kesler, 1961; Colucci et al., 1982; NRC, 2001). The size of the digestive tract can also be a factor [an example was provided by Aikman et al. (2008) for Holstein vs. Jersey cows]. Technique, mathematical model, and choice of digesta flow marker can also greatly affect passage rate estimates (Ellis et al., 1994; Hristov, 2005; Pellikaan et al., 2013). Extrinsic markers, for example, are likely to behave differently and yield shorter mean retention times (MRT) than intrinsic markers (Faichney et al., 1989). We proposed and tested an intrinsic digesta flow marker, acid-detergent insoluble ${ }^{15} \mathrm{~N}\left(\mathbf{A D I}-{ }^{15} \mathrm{~N}\right)$, which gave reasonable estimates of MRT in dairy cows (Huhtanen and Hristov, 2001), comparable to passage rates derived using Cr-labeled grass silage (Ahvenjärvi et al., 2004). The objective of the current study was to further evaluate ADI- ${ }^{15} \mathrm{~N}$ (from alfalfa hay) as a solid digesta passage marker compared with common extrinsic markers such as $\mathrm{Cr}$ and $\mathrm{Yb}$ (as Cr-mordanted and Yb-labeled alfalfa hay). Our hypothesis was that MRT of digesta derived from fecal excretion of intraruminally 
dosed ADI $-{ }^{15} \mathrm{~N}$ would be comparable to those derived from extrinsic markers.

Animals involved in this experiment were cared for according to the guidelines of and the experimental procedures were approved by The Pennsylvania State University Animal Care and Use Committee. The study was part of a larger experiment (Lee et al., 2011) utilizing 8 ruminally cannulated multiparous Holstein cows (mean \pm SD: parity, $2.8 \pm 0.7$ lactations; DIM, $102 \pm 28.4 \mathrm{~d}$; DMI, $26.4 \pm 0.27 \mathrm{~kg} / \mathrm{d}$; milk yield, $43 \pm$ $5.3 \mathrm{~kg} / \mathrm{d}$; and BW, $682 \pm 47.7 \mathrm{~kg}$ ). The design of the experiment was a replicated $4 \times 4$ Latin square, with 2 concurrent squares and four 21-d periods. Seven of the 8 cows on the main trial were used in the current experiment (1 cow was removed for health-related reasons that resulted in extremely low DMI). Treatments were as reported in Lee et al. (2011) and composition of the diets was similar to that reported in Lee et al. (2012). Briefly, the main trial had the following treatments: $15.6 \% \mathrm{CP}$ diet (MP balance: $-24 \mathrm{~g} / \mathrm{d}$ ), $14.0 \% \mathrm{CP}$ diet (MP balance: $-283 \mathrm{~g} / \mathrm{d}$ ), $14.0 \% \mathrm{CP}$ diet supplemented with $100 \mathrm{~g} /$ cow per day of rumen-protected Lys, and $14.0 \% \mathrm{CP}$ diet supplemented with $100 \mathrm{~g} /$ cow per day of rumen-protected Lys plus $24 \mathrm{~g} / \mathrm{cow}$ per day of rumenprotected Met. The diets contained (\% of DM): corn silage (31.7 to 32.7 ), alfalfa haylage (14.8 to 15.5$)$, grass hay (5.0 to 5.2), ground corn grain (14.4 to 18.1 ), bakery by-product meal (8.4 to 8.8 ), whole, heated soybeans (7.5 to 8.4), solvent-extracted soybean meal (1.7 to $5.3)$, cottonseed hulls, molasses, a urea source, mineralvitamin premix, and rumen-protected AA. The current experiment was conducted during the last $4 \mathrm{~d}$ of the last experimental period of the main experiment. For this part of the experiment, cows were moved and adapted to metabolic stalls. Urine was collected through urinary catheters (Hristov et al., 2010) and fecal samples were collected by stimulating defecation or from the rectum. Three solid digesta flow markers were studied: ADI- ${ }^{15} \mathrm{~N}$ from ${ }^{15} \mathrm{~N}$-labeled alfalfa hay and $\mathrm{Yb}$ - and Cr-labeled alfalfa hay. Nitrogen-15 labeled alfalfa was produced by fertilizing plants grown in a greenhouse with 10 atom $\%$ excess $\left({ }^{15} \mathrm{NH}_{4}\right)_{2} \mathrm{SO}_{4}$ (Isotec Inc., Miamisburg, $\mathrm{OH}$ ) as described by Melgar (2012) following the procedure of Hristov et al. (2001). Ytterbium- and Cr-labeled forage was prepared from one batch of alfalfa hay ground in a Wiley mill (A. H. Thomas Co., Philadelphia, PA) through a 4-mm sieve. The hay was sieved through a $1.18-\mathrm{mm}$ sieve, and the particles retained on the sieve were used in the labeling process. The Yb-labeled forage was prepared as described by Hristov and Broderick (1996). Briefly, alfalfa hay particles were incubated for $48 \mathrm{~h}$ in a neutral $\mathrm{pH} \mathrm{YbCl}_{3} \cdot 6 \mathrm{H}_{2} \mathrm{O}$ solution at $25^{\circ} \mathrm{C}$, washed thoroughly with tap water, soaked for $1 \mathrm{~h}$ in an acetic acid solution, and then washed again with tap water. Chromium-labeled fiber was prepared according to Udén et al. (1980), except that, as indicated above, the hay was first sieved through a $1.18-\mathrm{mm}$ sieve and the particles retained on the sieve were processed to isolate fiber. The $\mathrm{ADI}-{ }^{15} \mathrm{~N}$ labeled hay was from a different batch than that used in the Cr- and Yb-labeling process. Thus, results for ADI- ${ }^{15} \mathrm{~N}$ versus $\mathrm{Cr}-$ and $\mathrm{Yb}-$ labeled forage have to be interpreted with caution.

Labeled forages were dried for $48 \mathrm{~h}$ at $65^{\circ} \mathrm{C}$ in a forced-air oven and aliquots were ground in a Wiley mill through a 1-mm sieve for marker and chemical analyses. Nitrogen concentration and $\delta^{15} \mathrm{~N}$ of alfalfa hay-ADF were (DM basis) $0.78 \%$ and 5,807\%, respectively; $\mathrm{Cr}$ concentration was $7.7 \%$; and $\mathrm{Yb}$ concentration was $1.7 \%$. A single pulse dose of $150 \mathrm{~g}$ of air-dry alfalfa hay or fiber (in the case of $\mathrm{Cr}$ ) labeled with one of the above markers was mixed with about $10 \mathrm{~kg}$ of whole ruminal contents from each of the 7 cows on trial, returned to the rumen through the rumen cannula, and mixed with the ruminal contents. Following marker administration, fecal samples were collected at $0 \mathrm{~h}$ (background), 6, 8, 10, 12, 16, 24, 30, 42, 48, and $72 \mathrm{~h}$ postdose. Total urine collection was performed on $\mathrm{d} 1(24 \mathrm{~h})$ and $2(48 \mathrm{~h})$ following marker administration. Aliquots were analyzed for $\mathrm{Cr}$ and $\mathrm{Yb}$ by atomic absorption spectroscopy (Isaac and Johnson, 1985; University of Missouri-Columbia, Agricultural Experiment Station Chemical Laboratory, Columbia). Milk samples from d 1 and 2 following marker administration were also analyzed for $\mathrm{Cr}$ and $\mathrm{Yb}$. The diets fed in the trial did not contain supplemental $\mathrm{Cr}$ and it was assumed that all $\mathrm{Cr}$ in urine and milk was from the Cr-labeled forage, which may have slightly overestimated Cr secretion or excretion. Urine and milk were not analyzed for ${ }^{15} \mathrm{~N}$. Cows in the main trial received ${ }^{15} \mathrm{~N}$-Lys (Lee et al., 2011) and, although this could not have affected fecal ADI- ${ }^{15} \mathrm{~N}$ data, it was judged that ${ }^{15} \mathrm{~N}$ from ${ }^{15} \mathrm{~N}-$ Lys could have been released in milk and urine, thus confounding the ${ }^{15} \mathrm{~N}$ secretion or excretion data.

Fecal ADI- ${ }^{15} \mathrm{~N}, \mathrm{Cr}$, and $\mathrm{Yb}$ excretion data were fitted using 2-compartment mathematical age-dependent/ age-independent $\left(G_{n} \rightarrow G_{1}\right)$ models (Pond et al., 1988) as described in Huhtanen and Hristov (2001) and Hristov et al. (2003). Parameters were estimated using the nonlinear, least squares iterative process of SAS (SAS Institute Inc., Cary, NC). Criteria for best fit were (in order of priority) residual sum of squares, residuals distribution around the zero line, $95 \%$ confidence interval for the estimates, and $R^{2}$ values. The $G_{4} G_{1}$ model provided the best fit, and data based on this model were used in the statistical analysis and are presented in Table 1. Passage rate and MRT data were analyzed using the GLM procedure of SAS, with cow, diet, and marker as class variables and diet, marker, and diet $\times$ 
marker in the model. We detected no diet $\times$ marker interaction for any of the variables $(P=0.12$ to 0.87$)$ and therefore the diet interaction term was removed from the final model. Data were checked for normality using the UNIVARIATE procedure of SAS. When the W statistic of the Shapiro-Wilk test was $<0.90$ ( $\tau$, time delay; CMRT, cumulative MRT; and TMRT, total MRT), log-transformed data were analyzed statistically. Statistical differences were declared at $P \leq 0.05$. Differences between treatments at $0.05 \leq P \leq 0.11$ were considered as a trend toward significance. Data are presented as LSM. When the main effect of marker was significant, means were separated by pairwise $t$-test (pdiff option of PROC GLM).

Marker excretions in fecal matter followed the typical bell-shaped curve (Figure 1) observed in previous studies, in which digesta kinetics were estimated using similar approaches (Huhtanen and Hristov, 2001; Ahvenjärvi et al., 2004; Pellikaan et al., 2013). Peak marker concentrations were reached at about 24 to 30 $\mathrm{h}$ for all markers, which was again similar to data reported by Huhtanen and Hristov (2001) and Ahvenjärvi et al. (2004). Marker rate of passage in the first, agedependent compartment tended to be lower $(P=0.11)$ for $\mathrm{Yb}$ versus $\mathrm{Cr}$ and $\mathrm{ADI}-{ }^{15} \mathrm{~N}$ (Table 1). This resulted in a trend for longer $(P=0.07)$ MRT of $\mathrm{Yb}$ in the agedependent compartment, compared with $\mathrm{Cr}$ and ADI${ }^{15} \mathrm{~N}$. The rate constant for marker disappearance from the slow or age-independent compartment of digesta tended to be greater $(P=0.06)$ for $\mathrm{Yb}$ compared with $\mathrm{Cr}$ and ADI- ${ }^{15} \mathrm{~N}$. This led to a shorter $(P=0.01) \mathrm{MRT}$ of $\mathrm{Yb}$ versus $\mathrm{ADI}-{ }^{15} \mathrm{~N}(P=0.05$, when compared with $\mathrm{Cr})$ in this compartment. The cumulative MRT was longer $(P=0.03)$ for $\mathrm{ADI}-{ }^{15} \mathrm{~N}$ compared with $\mathrm{Yb}$ (a trend, $P=0.08$, when compared with $\mathrm{Cr}$ ). The total MRT in the digestive tract tended to be longer $(P=$ 0.10) for $\mathrm{ADI}-{ }^{15} \mathrm{~N}$ compared with $\mathrm{Yb}$.

Two of the markers tested in this study, $\mathrm{Cr}$ (as Cr-mordanted fiber) and ADI- ${ }^{15} \mathrm{~N}$, behaved similarly and resulted in similar compartmental or total MRT estimates. It is worth noticing that MRT in the ageindependent compartment (described as pre-duodenal digestion sites by Pond et al., 1988) tended to be longer when ADI- ${ }^{15} \mathrm{~N}$ was used as a marker versus $\mathrm{Cr}$. This could be an artifact of the labeling procedure (i.e., NDF in $\mathrm{Cr}$-mordanted fiber vs. acid detergent insoluble- $\mathrm{N}$ in ADI- ${ }^{15} \mathrm{~N}$ ), indicating longer MRT for ADF than NDF (see data and discussion in Huhtanen and Hristov, 2001).

Table 1. Marker passage kinetics in lactating dairy cows estimated from fecal samples

\begin{tabular}{|c|c|c|c|c|c|}
\hline \multirow[b]{2}{*}{ Parameter $^{1}$} & \multicolumn{3}{|c|}{ Marker $^{2,3}$} & \multirow[b]{2}{*}{$\mathrm{SEM}^{4}$} & \multirow[b]{2}{*}{$P$-value ${ }^{5,6}$} \\
\hline & $\mathrm{Cr}$ & $\mathrm{Yb}$ & ADI $-{ }^{15} \mathrm{~N}$ & & \\
\hline$\lambda, \mathrm{h}^{-1}$ & 0.294 & 0.223 & 0.301 & 0.0262 & $0.11^{7}$ \\
\hline$k, \mathrm{~h}^{-1}$ & 0.046 & 0.068 & 0.036 & 0.0079 & $0.06^{8}$ \\
\hline$\tau, \mathrm{h}$ & $2.2^{\mathrm{a}}$ & $2.6^{\mathrm{a}}$ & $0.6^{\mathrm{b}}$ & 0.71 & 0.01 \\
\hline $\mathrm{CMRT}_{1}, \mathrm{~h}$ & 14.5 & 19.0 & 13.9 & 1.43 & $0.07^{9}$ \\
\hline $\mathrm{CMRT}_{2}, \mathrm{~h}$ & $24.8^{\mathrm{a}}$ & $15.6^{\mathrm{b}}$ & $32.1^{\mathrm{a}}$ & 2.87 & $0.01^{10}$ \\
\hline CMRT, h & $39.3^{\mathrm{ab}}$ & $34.4^{\mathrm{b}}$ & $46.0^{\mathrm{a}}$ & 1.97 & $0.03^{11}$ \\
\hline TMRT, h & 41.5 & 36.6 & 46.6 & 2.31 & $0.10^{12}$ \\
\hline
\end{tabular}

${ }_{\mathrm{a}, \mathrm{b}}$ Within a row, means without a common superscript letter differ $(P<0.05)$.

${ }^{1} \lambda=$ rate constant for the first, age-dependent compartment; $k=$ rate constant for the second, age-independent compartment; $\tau=$ time delay; $\mathrm{CMRT}_{1}=$ mean retention time in the first, age-dependent compartment; $\mathrm{CMRT}_{2}=$ mean retention time in the second, age-independent compartment; CMRT $=$ cumulative mean retention time, $\mathrm{CMRT}_{1}+\mathrm{CMRT}_{2} ; \mathrm{TMRT}=$ total mean retention time, $\mathrm{CMRT}+\tau$.

${ }^{2}$ Markers: $\mathrm{Cr}=$ Cr-labeled fiber from alfalfa hay, $\mathrm{Yb}=$ Yb-labeled alfalfa hay, and $\mathrm{ADI}-{ }^{15} \mathrm{~N}=$ alfalfa hay intrinsically labeled with ${ }^{15} \mathrm{~N}$.

${ }^{3}$ Data were processed for outlier identification based on an absolute studentized residual value $>3$ (PROC REG of SAS; SAS Institute Inc., Cary, NC). Two cow/observations for $k$ were identified as outliers and were removed (together with the CMRT and TMRT estimates) from the statistical analysis.

${ }^{4}$ Largest SEM shown. Means are LSM; $\mathrm{n}=18$ to $21, \mathrm{n}$ represents the number of observations used in the statistical analysis.

${ }^{5} P$-value for the main effect of marker.

${ }^{6} \tau$, CMRT, and TMRT data were not normally distributed $(\mathrm{W}<0.90$; Shapiro-Wilk test, the UNIVARIATE procedure of SAS; SAS Institute Inc.) and the reported $P$-values are for log-transformed data.

${ }^{7} \mathrm{Yb}$ vs. $\mathrm{ADI}-{ }^{15} \mathrm{~N}, P=0.06$; $\mathrm{Yb}$ vs. $\mathrm{Cr}, P=0.09$.

${ }^{8} \mathrm{Yb}$ vs. ADI- ${ }^{15} \mathrm{~N}, P=0.02$; $\mathrm{Yb}$ vs. $\mathrm{Cr}, P=0.08$.

${ }^{9} \mathrm{Yb}$ vs. ADI ${ }^{15} \mathrm{~N}, P=0.03$; $\mathrm{Yb}$ vs. $\mathrm{Cr}, P=0.05$.

${ }^{10} \mathrm{Cr}$ vs. ADI ${ }^{15} \mathrm{~N}, P=0.10$.

${ }^{11} \mathrm{Cr}$ vs. ADI ${ }^{15} \mathrm{~N}, P=0.08$.

${ }^{12} \mathrm{Yb}$ vs. ADI- ${ }^{15} \mathrm{~N}, P=0.04$ 

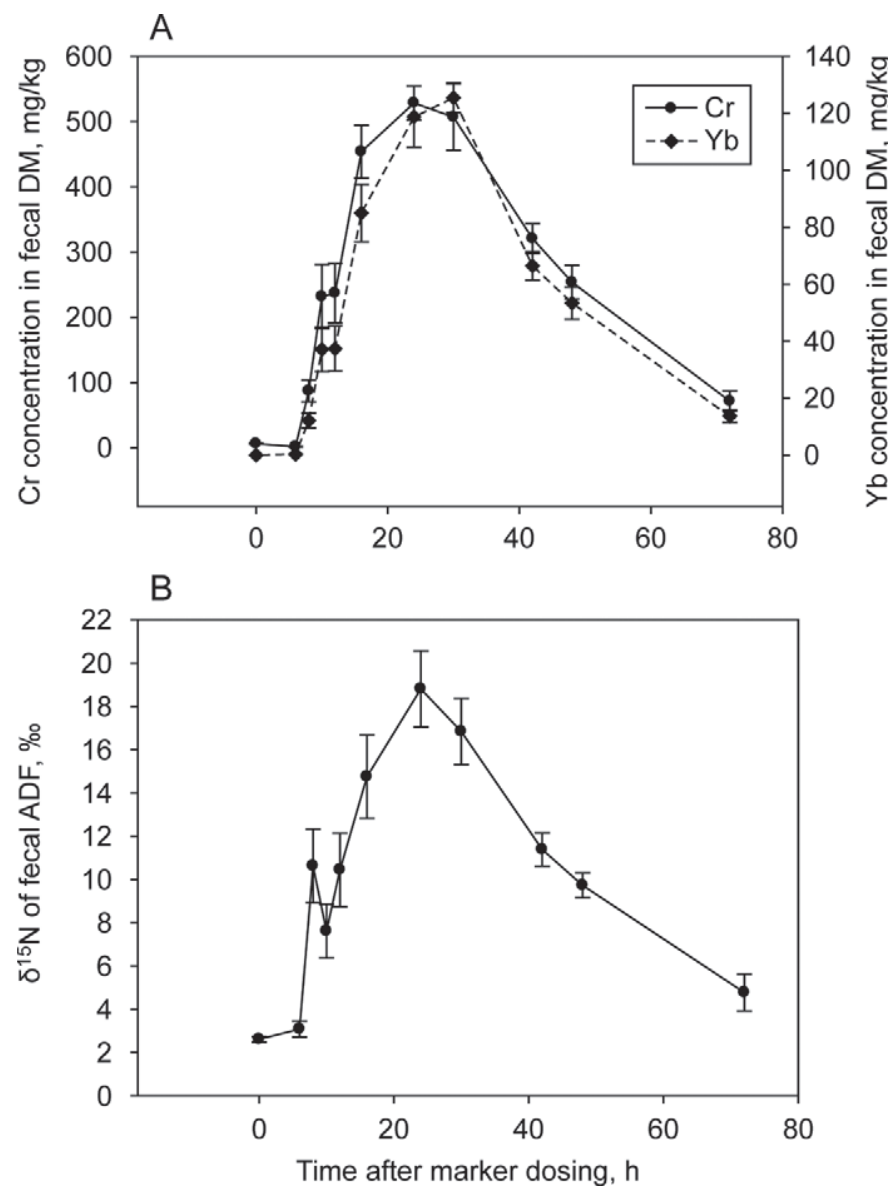

Figure 1. Marker excretion in feces (mean $\pm \mathrm{SE})$ : $\mathrm{Cr}=\mathrm{Cr}$-labeled fiber from alfalfa hay, $\mathrm{Yb}=\mathrm{Yb}$-labeled alfalfa hay (panel $\mathrm{A}$ ), and $\mathrm{ADI}-{ }^{15} \mathrm{~N}=$ alfalfa hay intrinsically labeled with ${ }^{15} \mathrm{~N}$ (panel B).

Recently, Pellikaan et al. (2013) reported contrastingly different compartmental and TMRT for Cr-NDF and ${ }^{13} \mathrm{C}-\mathrm{NDF}$ (plants were grown in ${ }^{13} \mathrm{CO}_{2}$-rich atmosphere). Those authors observed much greater fractional passage rates for $\mathrm{Cr}-\mathrm{NDF}$ versus ${ }^{13} \mathrm{C}-\mathrm{NDF}$, which resulted in more than 2-fold greater (although not statistically significant) retention times for the latter (up to $100 \mathrm{~h}$ with grass silage). Warner et al. (2013) compared digesta kinetics data for labeled ryegrass silage obtained using $\mathrm{Cr}-\mathrm{NDF},{ }^{13} \mathrm{C}-\mathrm{ADF}$, and ${ }^{15} \mathrm{~N}-\mathrm{ADF}$ (i.e., ADI ${ }^{15} \mathrm{~N}$ ) as markers and reported highest fractional ruminal passage rate and lowest TMRT with Cr-NDF $(k=0.047$ $\mathrm{h}^{-1}$ and $38.0 \mathrm{~h}$, respectively, where $k=$ rate constant for the second, age-independent compartment) and higher $k$ and shorter TMRT for ${ }^{15} \mathrm{~N}-\mathrm{ADF}\left(0.034 \mathrm{~h}^{-1}\right.$ and 46.4 h) than ${ }^{13} \mathrm{C}-\mathrm{ADF}\left(0.023 \mathrm{~h}^{-1}\right.$ and $\left.61.1 \mathrm{~h}\right)$. In contrast to $\mathrm{Cr}, \mathrm{Yb}$ (as Yb-labeled forage particles) produced longer MRT than both $\mathrm{Cr}$ and ADI- ${ }^{15} \mathrm{~N}$ for digesta in the fast, age-dependent compartment and considerably shorter MRT in the slower, age-independent compartment in the current study. The ratio of cumulative mean re- tention time in the first, age-dependent compartment $\left(\mathbf{C M R T}_{\mathbf{1}}\right)$ to CMRT tended to be greater $(P=0.06$; $\mathrm{SEM}=0.056)$ for $\mathrm{Yb}(0.54)$ than for $\mathrm{Cr}$ and $\mathrm{ADI}-{ }^{15} \mathrm{~N}$ (0.38 and 0.33, respectively). Similar observations for $\mathrm{Yb}$ were reported by Ahvenjärvi et al. (2004). These authors estimated $\mathrm{CMRT}_{1}$ :CMRT ratios of $0.58,0.40$, and $0.34\left(\mathrm{Yb}, \mathrm{Cr}\right.$, and ADI- ${ }^{15} \mathrm{~N}$, respectively) for labeled timothy grass silage. The most likely explanation for this discrepancy between $\mathrm{Yb}$ and $\mathrm{Cr}$ or $\mathrm{ADI}-{ }^{15} \mathrm{~N}$ is dissociation of $\mathrm{Yb}$ from the particulate matter in the second, age-independent compartment of ruminal digesta. The fact that $\mathrm{Yb}$ does not associate exclusively with the particulate matter in digesta has been reported by Siddons et al. (1985) and Combs et al. (1992). In the current study, forage samples were processed as suggested by Owens and Hanson (1992) to address the dissociation problem (see Hristov and Broderick, 1996), but this was probably insufficient to prevent $\mathrm{Yb}$ migration and produce reliable estimates of MRT in the age-independent compartment of digesta with this marker. The slower disappearance rate and longer retention time of $\mathrm{Yb}$ compared with $\mathrm{Cr}$ and $\mathrm{ADI}-{ }^{15} \mathrm{~N}$ in the first, age-dependent compartment is difficult to explain. Ytterbium has been reported to primarily associate with smaller digesta particles (Siddons et al., 1985) and bind to microbial mass in the rumen (Combs et al., 1992). If $\mathrm{Yb}$ is binding to microbial mass and microbes are preferably retained in the age-dependent compartment of rumen digesta, this may explain the longer residence time of $\mathrm{Yb}$ in this compartment, which, according to Pond et al. (1988), is the first compartment encountered by feed residues in their 2-compartmental model of digesta kinetics. We are not aware of studies that specifically investigated the relationship between digesta and microbial compartments (Chen and McAllister, 1997) in the rumen. In a recent study with Yblabeled fiber from corn and grass silages, Krämer et al. (2013) reported $\mathrm{CMRT}_{1}: \mathrm{CMRT}$ ratios of 0.25 to 0.38 . Thus, it appears that $\mathrm{Yb}$ may be useful as a particulate marker if applied to isolated fiber, not to the entire forage mass, as in the current trial.

Average concentrations of $\mathrm{Yb}$ and $\mathrm{Cr}$ in urine and milk collected over a 48 -h period following marker administration were $<0.002 \mathrm{mg} / \mathrm{L}$ (both urine and milk) for $\mathrm{Yb}$ and $0.14 \pm 0.004 \mathrm{mg} / \mathrm{L}$ in urine $(0.12$ and 0.18 , minimum and maximum) and $1.08 \pm 0.251 \mathrm{mg} / \mathrm{L}$ in milk (0.16 and 3.18, minimum and maximum) for Cr. Similar to our data, Siddons et al. (1985) infused CrEDTA and Yb-acetate intraruminally and reported about 3\% urinary excretion of the infused Cr but no urinary losses of $\mathrm{Yb}$ in wethers. Based on urine volume and milk yield data from the main trial (Lee et al., 2011), Cr secretion or excretion in milk and urine in the 48-h period following intraruminal administration 
of Cr-labeled feed was estimated at $0.79 \%( \pm 0.017$; minimum $=0.73$ and maximum $=0.86$ ) of $\mathrm{Cr}$ dose. Collectively, these data indicate no measurable losses of $\mathrm{Yb}$ along the digestive tract of ruminants but some absorption and excretion or secretion of $\mathrm{Cr}$.

In conclusion, this study confirmed previous observations that $\mathrm{ADI}^{-15} \mathrm{~N}$ can be reliably used as a solid digesta passage marker for ruminants, producing pre-duodenal and total-tract retention times similar to Cr-labeled fiber. Retention time of marker in the pre-duodenal sites was underestimated when $\mathrm{Yb}$ was used as a marker, emphasizing the need to process forages to isolate fiber before labeling with $\mathrm{Yb}$.

\section{REFERENCES}

Ahvenjärvi, S., A. Vanhatalo, A. N. Hristov, and P. Huhtanen. 2004. Passage kinetics of internal and external markers in lactating dairy cows. J. Anim. Feed Sci. 13:19-22.

Aikman, P. C., C. K. Reynolds, and D. E. Beever. 2008. Diet digestibility, rate of passage, and eating and rumination behavior of Jersey and Holstein cows. J. Dairy Sci. 91:1103-1114.

Chen, K.-J., and T. A. McAllister. 1997. Compartmentation in the rumen. Pages 492-522 in The Rumen Microbial Ecosystem. P. N. Hobson and C. S. Steward, ed. Blackie Academic and Professional, London, UK.

Colucci, P. E., L. E. Chase, and P. J. Van Soest. 1982. Feed intake, apparent diet digestibility, and rate of particulate passage in dairy cattle. J. Dairy Sci. 65:1445-1456.

Combs, D. K., R. D. Shaver, and L. D. Satter. 1992. Retention of rare earths by hay particles following incubation in fresh or autoclaved rumen fluid. J. Dairy Sci. 75:132-139.

Ellis, W. C., J. H. Matis, T. M. Hill, and M. R. Murphy. 1994. Methodology for estimating digestion and passage kinetics of forages. Pages $682-756$ in Forage quality, evaluation and utilization. G. C. Fahey Jr., M. Collins, D. R. Mertens, and L. E. Moser, ed. American Society of Agronomy, Madison, WI.

Faichney, G. J., C. Poncet, and R. C. Boston. 1989. Passage of internal and external markers of particulate matter through the rumen of sheep. Reprod. Nutr. Dev. 29:325-337.

Hristov, A. N. 2005. Feed quality: External flow markers. Pages 359361 in Encyclopedia of Animal Science. W. G. Pond, and A. W. Bell, ed., Marcel Dekker Inc., New York, NY.

Hristov, A. N., S. Ahvenjarvi, P. Huhtanen, and T. A. McAllister. 2003. Composition and digestive tract retention time of ruminal particles with functional specific gravity greater or less than 1.02 . J. Anim. Sci. 81:2639-2648.

Hristov, A. N., and G. Broderick. 1996. Synthesis of microbial protein in ruminally cannulated cows fed alfalfa silage, alfalfa hay or corn silage. J. Dairy Sci. 79:1627-1637.

Hristov, A. N., P. Huhtanen, L. M. Rode, T. A. McAllister, and S. N. Acharya. 2001. Comparison of the ruminal metabolism of nitrogen from ${ }^{15} \mathrm{~N}$-labeled alfalfa preserved as hay or as silage. J. Dairy Sci. 84:2738-2750.

Hristov, A. N., G. Varga, T. Cassidy, M. Long, K. Heyler, K. R. Karnati, B. Corl, C. J. Hovde, and I. Yoon. 2010. Effect of yeast culture on ruminal fermentation and nutrient utilization in dairy cows. J. Dairy Sci. 93:682-692.

Huhtanen, P., and A. N. Hristov. 2001. Estimating passage kinetics using fiber-bound ${ }^{15} \mathrm{~N}$ as an internal marker. Anim. Feed Sci. Technol. 94:29-41.

Isaac, R. A., and W. C. Johnson. 1985. Elemental analysis of plant tissue by plasma emission spectroscopy: Collaborative study. J. AOAC 68:499-505.

Krämer, M., P. Lund, and M. R. Weisbjerg. 2013. Rumen passage kinetics of forage- and concentrate-derived fiber in dairy cows. J. Dairy Sci. 96:3163-3176.

Krizsan, S. J., S. Ahvenjärvi, and P. Huhtanen. 2010. A meta-analysis of passage rate estimated by rumen evacuation with cattle and evaluation of passage rate prediction models. J. Dairy Sci. 93:5890-5901.

Lee, C., A. N. Hristov, K. S. Heyler, T. W. Cassidy, H. Lapierre, G. A. Varga, and C. Parys. 2012. Effects of metabolizable protein supply and amino acids supplementation on nitrogen utilization, production and ammonia emissions from manure in dairy cows. J. Dairy Sci. 95:5253-5268.

Lee, C., A. N. Hristov, H. Lapierre, T. Cassidy, K. Heyler, G. A. Varga, and C. Parys. 2011. Effect of dietary protein level and rumen-protected amino acid supplementation on dietary amino acid apparent digestibility and recovery in milk in lactating dairy cows. J. Dairy Sci. 94(E. Suppl. 1):689. (Abstr.)

Melgar, A. 2012. Rate and extent of utilization of ${ }^{15} \mathrm{~N}$-labeled alfalfa hay and alfalfa silage nitrogen fractions by mixed rumen microorganisms in vitro. MS Thesis. Univ. Idaho, Moscow.

NRC. 2001. Nutrient Requirements of Dairy Cattle. 7th rev. ed. Natl. Acad. Press, Washington, DC.

Owens, F. N., and C. F. Hanson. 1992. External and internal markers for appraising site and extent of digestion in ruminants. J. Dairy Sci. $75: 2605-2617$.

Pellikaan, W. F., M. W. A. Verstegen, S. Tamminga, J. Dijkstra, and W. H. Hendriks. 2013. $\delta^{13} \mathrm{C}$ as a marker to study digesta passage kinetics in ruminants: A combined in vivo and in vitro study. Animal 7:754-767.

Pond, K. R., W. C. Ellis, J. H. Matis, H. M. Ferreiro, and J. D. Sutton. 1988. Compartmental models for estimating attributes of digesta flow in cattle. Br. J. Nutr. 60:571-595.

Seo, S., C. Lanzas, L. O. Tedeschi, A. N. Pell, and D. G. Fox. 2009. Development of a mechanistic model to represent the dynamics of particle flow out of the rumen and to predict rate of passage of forage particles in dairy cattle. J. Dairy Sci. 92:3981-4000.

Seo, S., L. O. Tedeschi, C. G. Schwab, C. Lanzas, and D. G. Fox. 2006 Development and evaluation of empirical equations to predict feed passage rate in cattle. Anim. Feed Sci. Technol. 128:67-83.

Shellenberger, P. R., and E. M. Kesler. 1961. Rate of passage of feeds through the digestive tract of Holstein cows. J. Anim. Sci. 20:416-419.

Siddons, R. C., J. Paradine, D. E. Beever, and P. R. Cornell. 1985. Ytterbium acetate as a particulate-phase digesta-flow marker. Br. J. Nutr. 54:509-519.

Udén, P., P. E. Colucci, and P. J. Van Soest. 1980. Investigation of chromium, cerium, and cobalt as markers in digesta. Rate of passage studies. J. Sci. Food Agric. 31:625-632.

Warner, D., J. Dijkstra, W. H. Hendriks, and W. F. Pellikaan. 2013. Passage of stable isotope-labeled grass silage fiber and fiber-bound protein through the gastrointestinal tract of dairy cows. J. Dairy Sci. 96:7904-7917. 